\title{
Specify NF1 Mutation
}

National Cancer Institute

\section{Source}

National Cancer Institute. Specify NF1 Mutation. NCI Thesaurus. Code C160581.

A request to enter the specific NF1 mutations that were identified in the study. 